By ROBERT B. DOWNS

\section{Libraries in Minuscule}

$\mathrm{F}$ OR THE LAST TWO DECADES a revolution has been in progress in libraries-a transition in some respects as spectacular as the change-over from the manuscript to the printed book in the fifteenth century. The momentum of the new movement is increasing yearly, and threatens to upset many traditional practices in the operation of libraries.

Since the mid-nineteen-thirties, vast quantities of printed and manuscript materials have been reduced from their normal proportions to miniature forms. A return to the ancient roll form-the microfilm - plus flat-surface microcards and microprints, have compressed millions of pages of periodicals, newspapers, government publications, early imprints, dissertations, manuscripts, archives, bibliographies, and a variety of other records into a fraction of their original bulk.

The reasons for the revolution are diverse. In some instances, no doubt, there have been gadget-happy individuals at work, people who are convinced that the book in its orthodox shape is obsolete, and determined to convert the whole great world of library materials into a microcosm. Better balanced persons, however, have recognized both the potentialities and limitations of the new media. They have seen the immense value of micro-reproductions in preserving fragile records, in saving war-endangered materials from possible destruction, in increasing the availability of unique and rare items, in saving storage space, and,' in the case of works of highly specialized interest, for original publication. At the

This paper was presented at the TriState Chapter meeting of ACRL, Cleveland, Ohio, May 19, 1956. Dr. Downs is director of the Library and Library School, University of Illinois. same time, they realize that by no means all library collections are as useful in micro-reproduction as in their original formats. In short, we have here an extraordinarily important and versatile auxiliary device for strengthening library resources and service, but we should view it as only one weapon in our varied arsenal, a means not an end.

A review of the major projects for micro-reproduction, completed or in process, will reveal some of the accomplishments, as well as the diversity of uses, of these modern techniques. For the purposes of this survey, we need not be particularly concerned with whether the medium is microfilm, microcard, or microprint. Each has advantages and disadvantages, but at the present stage there is little likelihood of uniformity. All three methods are reasonably satisfactory for most types of material. In any case, a library which enters the field of microreproduction to any considerable extent will need to provide itself with mechanisms to read all the principal forms of microtexts.

In no area, perhaps, are the potentials of micro-reproductions greater than with early imprints. Here we are dealing with works which because of age, natural attrition, and other factors are nearly always in short supply. Frequently, they are known only in unique copies. All the available copies may be located in old, established institutions, or if a copy does come on the market, there will be competition for it among a number of libraries and the price will be exorbitant. Furthermore, no matter how large and wealthy the library, it can never expect to have more than a fraction of, say, the known incunabula or the original Shakespeare quartos. There are not enough in existânce to go around. Here is a signal opportunity for microtexts. 
There are two outstanding undertakings in the early imprint field, one concerned with English books before 1640 and the other with American books before 1800 . The first, inaugurated in the thirties by University Microfilms, will ultimately include all titles, numbering over 30,000 , printed in the British Isles or in English from 1475 to 1640 . The project is 60 per cent completed, and about 100,000 pages annually are being produced. More recently begun is the American Antiquarian Society's microprint edition of American imprints from 1639 to 1800 . Based primarily upon Evans' American Bibliography, the aim will be to reproduce the complete text of every existent book, pamphlet, and broadside in what is now the United States for the first 161 years of our printing history. More than 35,000 titles will be included, and it is planned to complete the project within ten years.

A similar enterprise is the Louisville Free Public Library's Evans-Sabin Microcard Project, which is issuing $2,500 \mathrm{mi}$ crocards per year, representing some 100,000 pages of print. Currently, the material to be reproduced is being drawn largely from the Americana collection of Thomas Jefferson in the Library of Congress.

Still another project, known as the New American Culture Series, at the University of Michigan, is undertaking to microfilm $6,000-7,000$ rare books pertaining to American civilization published before 1876. Approximately 100,000 pages will be produced each year, and five or six years will be required for completion of the program. This series is a continuation of the American Culture Series, done in 1941, which filmed and distributed a highly selected group of 250 basic items of Americana, beginning with the 1493 Columbus letter and ending with the year 1800 .

This is an area, by the way, in which it seems difficult to avoid overlapping among various interests. The program sponsored by Louisville, however, is making an effort to avoid conflict with other projects in the field.

Another natural for microphotographic processes, though for different reasons, is newspapers. Because of fragility and bulk, newspapers constitute a perennial problem to libraries trying to preserve them. According to the current Ayer's Directory, there are over 11,400 newspapers presently being published in the United States-1,860 dailies, and the remainder weeklies, semiweeklies, etc. A conservative estimate is that less than one-half the total are preserved in libraries. The others sink without a trace-a serious loss for history, since even the most mediocre papers contain local and regional news that never appears in any other source. When the papers disappear, the record is lost. The burden and expense of maintaining complete files of all newspapers, even for a single state, however, is ordinarily too great for any one library. That is one of the main impulses behind a number of large cooperative filming projects. Incidentally, of the three principal media, microfilm, rather than microcards or microprint, appears to be best adapted to newspapers.

Projects for the reproduction of newspaper files, current and retrospective, American and foreign, are innumerable. One of interest is the Association of $\mathrm{Re}$ search Libraries' establishment of a national pool of newspapers on microfilm, located at the Midwest Inter-Library Center in Chicago. The plan, which began with January 1, 1956, issues, provides for the current acquisition of about 100 leading foreign newspapers, paid for by some 46 participating libraries. These libraries have the privilege of borrowing positive films and of purchasing prints at cost.

The ARL program may be thought of as a continuation and expansion of another undertaking in the foreign field, the Harvard Newspaper Microfilm Project, which began in 1938. Approximately 640,000 feet of negative film of 62 foreign 
newspapers, reproduced by Harvard between 1938 and 1955, have recently been transferred to the Midwest Center. The ARL and Harvard materials are further supplemented by the Center's own collection of 57 foreign newspapers on microfilm received currently since January, 1952. This is an area, also, in which the Library of Congress has long been active; scores of foreign newspaper files, past and present, are being copied there.

As for American newspapers, scarcely a day passes without an announcement of a new filming project. In 1953 the Library of Congress issued the second edition of the union list Newspapers on Microfilm. Well over 4,000 titles in 275 libraries were recorded. Since then, the movement has accelerated and hundreds of additional titles have been added. There appears to be an increasing tendency to manage the problem on a statewide basis, rather than by any piecemeal approach. Among the states which have made notable advances in placing their papers on film are California, Colorado, Florida, Georgia, Kansas, Kentucky, Louisiana, Missouri, Nebraska, Oregon, Utah, Washington, West Virginia, and Wisconsin. Usually, one or two institutions in each state have taken the lead. For example, the University of California Library at Berkeley has microfilmed files of about 400 California newspapers, with emphasis on nineteenth-century material; the Nebraska State Historical Society has filmed 186 Nebraska papers; and projects of similar scope are being carried on by the Kansas State Historical Society, Washington State Library, Louisiana State University and the University of Utah, among others. In a number of instances, these undertakings are aided by substantial special appropriations from state governments, as is true in California, Kentucky, Louisiana, Nebraska, and Washington.

Several projects have involved newspapers in special categories. Four examples come to mind. First is the Wisconsin State
Historical Society's extensive program for microfilming labor papers, which, at last report, included 75 official journals published by national and international unions and more than 100 local labor newspapers representing all parts of the United States and Canada. The second is the collection of Negro newspapers filmed by the Library of Congress for a project sponsored by the American Council of Learned Societies; over 200 titles of historical and current interest were included. The third is a series, done by University Microfilms, of about 50 Irish newspapers of the period 1685 to 1752 , believed to contain all surviving Irish papers of the era. The last is the Wisconsin State Historical Society's program for filming all Scandinavian language newspapers published in the United States.

Not all newspaper filming, of course, is being done by libraries or for libraries. As one illustration of this fact, MicroPhoto, Inc., of Cleveland, Ohio, is currently filming scores of American papers from throughout the country, chiefly by arrangement with publishers and for publishers, though copies are available to libraries.

Turning now to the periodical field, reproduction programs are fully as numerous as in the newspaper area. Of general interest are three projects being carried on by University Microfilms, Inc. Specialists in English literature have selected about 200 English literary periodicals of the seventeenth, eighteenth, and nineteenth centuries to be filmed in their entirety. Some 40 titles have been completed to date. The plan is to produce approximately 100,000 pages annually until the undertaking is finished. Second is the reproduction of American periodicals prior to 1850 . This series comes in two parts: one, all known and located periodicals issued before 1800 , comprising about 75,000 pages; and two, selected periodicals for the next half century, 1800 to 1850 . For this program, also, distribution will be at the rate of 100,000 
pages per year until completed. A third University Microfilms enterprise is concerned with current periodicals. Nearly 900 journals in a wide range of subjects are being filmed as they appear and sold by subscription. A special arrangement, however, governs sales. In the first place, with occasional exceptions, to avoid loss to the publisher a library must also subscribe to the regular paper edition of a journal; then, at the end of the volume year, the microfilm copy is delivered. The cost of the film copy approximates the cost of binding the same material, and the assumption is that the original paper copies will never be bound. Instead, they will be kept until the period of greatest use is over or until worn out, at which time the paper copies will be discarded and microfilm substituted.

Other periodical projects are too numerous for detailed description. Some 95 complete files of periodicals on microfilm, predominantly scientific and technical, are available from University Microfilms. The Microtext Publishing Corporation of New York offers full sets of about 70 scientific and technical journals on microcards. Another group of such journals is available from the Microcard Foundation and the Technical Microcard Publishing Corporation. Smaller programs, for the reproduction of one or more periodical files, are common.

The fourth major category to be considered is government publications, and the scope of some of the micro-reproduction enterprises in that field is somewhat staggering, especially to library budgets. In the international sphere, the most colossal undertaking is the Readex Microprint Corporation's publication of all unrestricted documents of the United Nations, for the period 1946-1953. Over $1,000,000$ pages, covering 25,000 documents, will be included in the project scheduled to be completed in 1957. According to the publisher's announcement, current publications of the United $\mathrm{Na}$ tions, starting with 1954, will also be is- sued in microprint, on a yearly basis.

Another large microprint publishing venture, under way for the past decade or more, is for British documents. All British House of Commons Sessional Papers from 1731 to 1900 are being reproduced, amounting to the impressive total of 80,000 documents in $4,600,000$ pages. The Journal of the House of Commons for 1547-1900, called "the longest continuous parlimentary record in the world," is also available in microprint.

As though these huge programs were not enough to occupy any publishing organization indefinitely, the Readex Corporation has moved into United States Government publications on several fronts. The first, beginning with 1953, covers non-depository publications, numbering about 12,000 titles annually. The second, on a current basis, reproduces all depository publications, estimated at 60,000 pages per year. These two projects combined will include all documents about 20,000 annually-listed in the Monthly Catalog of the Superintendent of Documents. Still another program is engaged in issuing a microtext edition of the United States Government serial set, beginning initially with the period 18171825 , with probably other sections to follow.

On a somewhat less ambitious scale, several other organizations are likewise concerned with this field. University Microfilms is issuing the Congressional Record and its predecessors back to 1789 , and hearings, reports, and committee prints for recent Congresses. The Microcard Foundation has reproduced the early $A n$ nals of Congress and is distributing currently microcard editions of the Patent Office Official Gazette and the U. S. Federal Register. Such specialized items as the Voice of America broadcast scripts and the daily reports of foreign radio broadcasts are available on microfilm from the Library of Congress Photoduplication Service.

It might be noted that relatively little 
duplication occurs in these various projects. The Federal Register and the Patent Office Official Gazette are offered in both microfilm and microcard forms. The Congressional committee prints are available separately on microfilm and also appear in the microprint set of non-depository documents.

The most extensive undertaking in the state documents field was a cooperative program between the Library of Congress and the University of North Carolina, from 1941 to 1950 , to microfilm the significant statutory, constitutional, executive, administrative, judicial, and legislative records of the American colonies, territories, and states. The total fills 1,700 rolls of microfilm, reproducing nearly $3,000,000$ pages of material for all the 48 states. An 800-page printed guide renders the great mass of records readily accessible. The master negatives of the project are deposited in the Library of Congress and positive copies may be purchased through the Library's Photoduplication Service.

The fifth of the large general categories of material to be of active concern for micro-reproduction purposes is manuscripts and archives. This, too, is a "natural," because manuscript collections are always unique, ordinarily existing solely in single original copies, and they can only be made more widely available through some form of reproduction. Furthermore, the mass of most archival and manuscript collections is so great as to preclude any type of duplication except by one of the comparatively economical microtext techniques.

Examples of the application of microphotography to the manuscript field are offered by several projects for the reproduction of the papers of public figures. In 1947, the Library of Congress made available complete microfilm copies of all items in the Abraham Lincoln collection presented by Robert Todd Lincoln; included were 18,350 documents and 41 ,751 numbered leaves - an invaluable source for historians. Another noteworthy enterprise, sponsored by the Massachusetts Historical Society and other organizations, is the microfilming of the public and private papers of the Adams family, who have played such an important part in American affairs for the past two centuries. In the 300,000 manuscript pages being reproduced are the records left by John, Abigail, John Quincy, Charles Francis, Henry, Brooks, and other prominent members of the Adams clan.

Still another American President, James K. Polk, has had his correspondence reproduced by microfilm. This was a cooperative project done by the Library of Congress Photoduplication Service for a dozen research libraries. A total of 42,771 exposures was required to cover the Polk letters in the Library of Congress.

American libraries are also branching out into foreign fields. Under a grant from the Rockefeller Foundation, more than 100,000 unpublished manuscripts of Gottfried Wilhelm Leibniz, who has been termed "the most universal scientific genius of modern times," are being microfilmed in Hanover, Germany, and the film deposited at the University of Pennsylvania Library.

In the archival area, there are enterprises of even larger proportions. A recent catalog of microfilm publications of the National Archives lists reproductions of over $3,000,000$ pages of records. These provide basic documentation for research in American, European, Far Eastern, and Latin American history, as well as in local and regional history and genealogy. Additions are constantly being made to the list.

One of the most extensive microfilming operations was carried on during the war years by the American Council of Learned Societies and the Library of Congress. To preserve valuable historical, scientific, and literary manuscripts from destruction, nearly $5,000,000$ pages of material were filmed in England and 
Wales. The collection is now deposited at the Library of Congress, from which positive copies may be obtained.

Great bodies of archives of foreign governments have also been reproduced. Here are a few notable examples: (1) The Library of Congress, in cooperation with the U. S. Department of State, microfilmed more than 2,000,000 pages of records in the Japanese Ministry of Foreign Affairs for the period 1868-1945; (2) the University of California Library, Berkeley, is engaged in filming parts of the German Foreign Ministry Archives for the period 1867-1920; (3) also at the University of California, about 75,000 pages of selected Philippine archives have been filmed, predominantly for the Spanish period of Philippine history; (4) in 1951 the Library of Congress completed copying the diplomatic correspondence between the Ministry of Foreign Relations in Mexico City and the Mexican Legation in Washington, for the period 1853-1898.

In the foreign field, too, are several other projects of extraordinary interest carried through by the Library of Congress. What was described as "priceless and heretofore almost completely inaccessible collections in what is believed to be the world's oldest Christian monastery," at the Monastery of St. Catherine on Mount Sinai, were filmed. Between 500,000 and 700,000 pages were reproduced. Of similar nature is an important microfilming project carried out in Jerusalem, where 3,000 ancient and medieval manuscripts, dating back to the sixth century, were filmed in the Greek Orthodox Patriarchate Library. This work was extended later to include the Armenian Patriarchate Library.

Of even greater magnitude is a project, now in progress, for microfilming manuscripts in the Vatican Library. To protect and make more widely available these historic documents of the Christian world, the Knights of Columbus Foundation is having reproduced about 42,000 manuscripts and codices in the Vatican Library. The microfilms are being deposited in the St. Louis University Library.

Several religious groups in the United States have also arranged for the reproduction of their records. For example, the University of Chicago microfilmed a comprehensive corpus of Lutheran books and periodicals published during the first hundred years of English-speaking Lutheranism in America; the Southwestern Baptist Theological Seminary in Fort Worth sponsored the microfilming of 1,127 of the more important Baptist books, tracts, pamphlets, manuscripts and records between 1526 and 1837, totaling more than 100,000 pages; and Southern Methodist University has had microfilmed complete runs of several leading Methodist journals.

This brings us logically to a brief review of micro-reproduction enterprises in other subject fields. In literature, a program of unusual significance is the Readex Microprint Corporation's microprint edition of over 5,000 English and American plays, covering the period 1500-1800 for England and to 1830 for America. Of related interest is a project for microfilming source materials in the theatre field. Under the sponsorship of the Speech Association of America, University Microfilms is reproducing monographic works on acting, ballet and opera, theatre history, theory and criticism, production and stagecraft, and complete files of five theatrical periodicals, a total of some 47,000 pages.

Two smaller projects in the literary area are the microfilmed series, also sponsored by the Speech Association of America, of early British and Continental works in rhetoric and elocution; and the Lost Cause Press' series of nineteenthcentury American literature on microcards, principally works of local and regional interest.

In the fine arts, two programs in music and musicology have developed. A series of microcard publications, including 
theses, early music books, and music periodicals, is being issued by the University of Rochester. Similar material on microfilm is available from the Research Microfilm Publishers, Superior, Wisconsin. Also classifying in the art field is a microfilm history of painting, with 4,000 pictures from 1300 A.D. to the present, ready to be mounted as slides, issued by University Microfilms.

In no subject field, probably, have the micro-reproduction processes been of more value than in science and technology, especially for journals and research reports. A noteworthy instance is the $\mathrm{Mi}$ crocard Foundation's issuance of the several thousand unclassified Atomic Energy Commission Reports, dealing with physics, chemistry, mineralogy, engineering, mathematics, and medicine. These reports are also available in microform from the Hitchcock Publishing Company of Washington.

The various report series emanating from the National Advisory Committee on Aeronautics are being republished, from the beginning in 1915 , by the Microcard Foundation; the total of such reports is over 9,000 .

In the journal field, numerous scientific and technical titles are being reproduced, retroactively and currently, by University Microfilms. The work of the Microcard Foundation is likewise outstanding in this area, for it has a long list of periodicals and large sets in biology, chemistry, geography, geology, physics, and general science available on microcards.

Also on microcards, the University of Rochester is publishing a number of medical journals and theses, by special arrangement with the Microcard Foundation.

The contributions of micro-techniques to the field of history are likewise significant. Some years ago, Brown University undertook to copy all books and documents that could be located, published prior to 1800 , dealing with the early civi- lization of Latin America. The Microcard Foundation has reproduced the great 235-volume Rolls Series for British medieval history. Under the sponsorship of the Committee on Documentary Reproduction of the American Historical Association, the Readex Microprint Corporation has issued a series of Russian historical sources, totaling 500,000 pages. These are a few of many examples.

Several projects in miscellaneous fields should be noted. Seventy American universities have an arrangement with University Microfilms to microfilm about 5,000 doctoral dissertations annually, and to sell positive copies. Those available are listed periodically in Dissertation Abstracts. The University of Oregon is issuing a substantial number of microcard publications in health, physical education, recreation, and allied areas. Also on microcards is the Microcard Foundation's continuing project for reproducing corporation annual reports; about 1,900 corporations listed on the New York and American' Stock Exchanges are included. Finally, in library science, the ACRL Microcard Series is covering works in librarianship and bibliography not considered suitable for publication in conventional forms.

As one surveys the multiple areas in which micro-reproduction is operating and the vast amount of activity in the field, the effect is rather overwhelming. One might gain the impression that soon the whole world of library materials will be in microtext form. That, of course, is far from being the case, for actually micro-reproduction thus far is functioning in fairly limited spheres. Nevertheless, it is making widely available great quantities of little-used, rare, and hitherto inaccessible books, documents, journals, newspapers, manuscripts, and other records. In that way, American library resources for advanced study, research, and scholarship are being immensely strengthened and enriched.

The number and cost of the microform 
programs are becoming an increasing problem to libraries, and particularly to the principal research libraries that attempt to subscribe to all projects they consider worth-while. A larger and larger share of book budgets is being diverted in this direction. The substantial expenditures required to keep up with the field are doubtless defensible, but the microtexts may be useful mainly from a longrange point of view, while libraries must continue to provide books and other publications in their traditional form to meet current demands.

From the point of view of colleges and the smaller universities, the answer, as with any other library materials, is selection. Exactly the same principles should govern the purchase of micro-reproductions as printed books and periodicals. Almost without exception, originals are preferable to microtexts, because they are nearly always easier to use. Frequently, however, it is a microtext or nothing. The advisability of buying current publications, such as much-used periodicals, in anything except the original paper form is questionable. Some space and binding costs may be saved, but at the expense of satisfactory service.

For the large university and research library, it may be highly desirable to participate in most of the projects described above. In some instances, the load may be lightened by cooperative arrangements among neighboring institutions, as is being done, for example, between Duke University and the University of North Carolina. For libraries with more limited needs, however, it is difficult to justify the considerable expenditures that would be called for by subscriptions to such programs as all English books before 1640, all American books before 1800, British Sessional Papers of the eighteenth and nineteenth centuries, all United Nations publications, and similar ambitious undertakings. In many cases, it should be noted, it is not required that a library agree to accept everything pro- duced by a given project. Instead, without being committed to take the entire lot, it is often permitted to buy a specific journal file, a particular book or other item, just as with materials in different formats. For libraries with restricted needs and limited budgets - and most libraries fall in that category-this is an intelligent approach and a good working solution. There is a temptation, which has to be resisted, to be swept off one's feet by the inspiring thought that here is an opportunity to provide our library clienteles with rare books and journals and great masses of primary sources hitherto unavailable to them. If these littleused materials are to be bought with funds more urgently needed for current publications, on the other hand, the librarian has to use his best judgment in deciding which should come first.

Viewed objectively, micro-reproduction is not a universal panacea or an answer to all the problems of research libraries. Microfilm, microcards, and microprint have joined the wide range of auxiliary tools developed in recent years to complement the book as we have known it for the past 500 years. Libraries are increasingly affected by technology. The sound recording, the documentary film, the film strip, the slide, FM radio, closed TV installations, and electronic facsimile transmission systems are among the instruments which librarians now and in the future will be able to add to their rich repertoire for the dissemination of ideas. Books, however, at least in the foreseeable future, will remain the basic tools of libraries. It is to be doubted that anyone will ever feel inclined to curl up in bed with a microcard or a roll of film. And call it prejudice if you will, it is unlikely that any scholar or student in his right mind would choose a microfacsimile in place of the original document. The reproduction is a valuable substitute, but it will almost certainly continue to run second in the affections of library users everywhere. 